\title{
INFLUENCE OF THE SURFACE ROUGHNESS OF PARTICLEBOARDS AND THEIR PERFORMANCE TOWARDS COATING
}

A. Rolleri ${ }^{1}$, E. Roffael ${ }^{2}$

\begin{abstract}
The effect of surface properties on the quality of the adhesion was evaluated for coated particleboards. Uncoated UF- and TF-bonded particleboards made using different raw materials were conditioned under $20^{\circ} \mathrm{C}$ and $65 \%$ relative humidity and coated with a nitrocellulose lacquer primer by a conventional process. The interaction between the primer and surface seems to be a very important factor determining the strength of adherence.
\end{abstract}

Keywords: roughness, moisture, MDF

\section{RESUMEN}

Las propiedades de la superficie y su efecto en la calidad de la adhesion fueron evaluadas en tableros pintados. Tableros de partículas sin recubrir encolados con resinas UF y TF hechos utilizando diferentes materias primas fueron acondicionados a clima $20^{\circ} \mathrm{C}$ and $65 \%$ de humedad relativa fueron pintados con un aparejo nitrocelulósico mediante un proceso convencional. La interacción entre el aparejo y la superficie parece ser un importante factor que determina la fuerza de la adherencia.

Palabras claves: rugosidad, humedad, MDF

\section{INTRODUCTION}

One of the most important surface properties of wood-based panels is their roughness. It can be defined as the measure of the fine irregularities of a surface. Their size and frequency establish the surface quality. In case of painted or overlaid composite boards irregularities may have a negative impact on the adhesion of paints and overlays and so far on the quality of the final product (Hiziroglu 1998).

The surface roughness defines how a surface feels, looks and how it works in contact with another surface as well as how it behaves by overlaying or painting (PDI, 1998). The characterization of a surface employs mathematical and statistical parameters for its interpretation. The most important parameter is the so called average roughness $\left(\mathrm{R}_{\mathrm{a}}\right) \cdot \mathrm{R}_{\mathrm{a}}$ is determined as the height of a rectangle with length $l_{\mathrm{m}}$ and the same area as between the surface profile and the mean line (Östman 1983).

The performance of any wood surface towards coating is determined by the natural characteristics of the wood species and the manufacturing processes used (Cassens 1991, Richter et al. 1995). One basic requirement for durable paint performance on the surface of wood-based panels is a good adhesion between the wood surface and the coating material. Manufacturing parameters such as the mixture of round timber types, the amount of adhesives, sanding, storage and conditioning of the boards appeared to be closely linked with the surface properties and their performance towards coating (Barbu et al. 2000). 
In this work, most of the manufacturing variables for particleboards were kept constant in order to visualize the specific effect of the raw materials and resins. These include effect of fresh wood particles, recycling particles and recycling cork particles on the surface properties of wood-based particleboards bonded with a urea-formaldehyde resin (UF-resin), and a tannin-formaldehyde resin (TF-resin).

The main objective of this study was, therefore, to evaluate the influence of different raw materials and resins, in the surface roughness of particleboards and their performance towards coating.

\section{MATERIAL AND METHODS}

Three layer particleboards were produced using different raw materials in the surface and different resins. The raw materials used for the surfaces of the particleboards were industrially produced fresh particles, recycled particles from industrially produced UF-bonded particleboards and recycled cork particles. For the core layers of the chipboards industrial produced fresh particles were used in all cases.

The fresh particles for the surface and core layers of the particleboards were supplied by a German particleboard company. The particles were a mixture of Picea abies (Spruce) and Pseudotsuga menziesii (Douglas fir). The size of the fresh surface particles was between $0.2 \mathrm{~mm}$ and $1.0 \mathrm{~mm}$.

The same company offered $19 \mathrm{~mm}$ uncoated urea-formaldehyde bonded particleboards for the production of recycled surface particles. The recycled particles were produced by a dry process in the laboratories of the Institute of Wood Biology and Wood Technology. Therefore, the UF-bonded particleboards were cut into pieces of $5.0 \mathrm{~cm} \times 5.0 \mathrm{~cm}$ and thereafter grinded with a special aggregate (Electra industrie). After the grinding process the recycled particles were screened and classified according to their sizes. Only recycled particles between a size of $0.2 \mathrm{~mm}$ and $1.0 \mathrm{~mm}$ were used for the surface layers of recycling particleboards.

The cork particles were supplied by a German company. The cork particles were also meshed and classified between a range of $0.2 \mathrm{~mm}$ and $1.0 \mathrm{~mm}$.

For preparation of particleboards a commercial urea-formaldehyde resin (UF-resin, BASF K 350 ) and a tannin-formaldehyde resin (TF-resin) were used. The fresh and recycled particles were dried to moisture content (MC) of $4 \%$, the cork particles were dried to moisture content (MC) of $2 \%$.

The factorial considers as independent variables, the raw material with three levels and resin with two levels. The factorial generated six interactions see Table 1.

Table 1. Interactions or treatments considered in the experimental design

\begin{tabular}{|c|c|c|}
\hline INTERACTIONS & RAW MATERIALS & RESINS \\
\hline 1 & Fresh particles & Urea formaldehyde \\
\hline 2 & Fresh particles & Tannin formaldehyde \\
\hline 3 & Recycling particles & Urea formaldehyde \\
\hline 4 & Recycling particles & Tannin formaldehyde \\
\hline 5 & Cork particles & Urea formaldehyde \\
\hline 6 & Cork particles & Tannin formaldehyde \\
\hline
\end{tabular}


Six different variants of particleboards were made maintaining constant the density in all of them; from each type one boards were produced. In Table 2 the conditions of board preparation are compiled.

After production the particleboards were trimmed to the target dimensions (410 mm x 410 $\mathrm{mm}$ ) and sanded (grain 120) to the target thickness $(19 \mathrm{~mm})$. Thereafter, the particleboards were conditioned about four weeks prior to evaluating their surfaces at $20^{\circ} \mathrm{C} / 65 \%$ relative humidity of climatic conditions.

The surface roughness of the particleboards was then measured by using a Perthometer (model S4P). The measuring begins with the calibration of the instrument. In this experiment the length of the traverse LT, was $5.6 \mathrm{~mm}$ and the vertical limit (VB) was $250 \mu \mathrm{m}$. For each variant ten measurements were taken systematically all over the surface. During each measurement the parameters $R_{a}$ was calculated by Perthometer software.

Table 2. Conditions for preparation of the tested boards

\begin{tabular}{|c|c|c|c|c|c|c|}
\hline & variant 1 & variant 2 & variant 3 & variant 4 & variant 5 & variant 6 \\
\hline Surface layer & fresh particles & fresh particles & recycled particles & recycled particles & cork particles & cork particles \\
\hline Number of boards & 1 & 1 & 1 & 1 & 1 & 1 \\
\hline Layers & 3 & 3 & 3 & 3 & 3 & 3 \\
\hline Target density & $700 \mathrm{~kg} / \mathrm{m}^{3}$ & $700 \mathrm{~kg} / \mathrm{m}^{3}$ & $700 \mathrm{~kg} / \mathrm{m}^{3}$ & $700 \mathrm{~kg} / \mathrm{m}^{3}$ & $700 \mathrm{~kg} / \mathrm{m}^{3}$ & $700 \mathrm{~kg} / \mathrm{m}^{3}$ \\
\hline Size of the boards & $410 \mathrm{~mm} \times 410 \mathrm{~mm}$ & $410 \mathrm{~mm} \times 410 \mathrm{~mm}$ & $410 \mathrm{~mm} \times 410 \mathrm{~mm}$ & $410 \mathrm{~mm} \times 410 \mathrm{~mm}$ & $410 \mathrm{~mm} \times 410 \mathrm{~mm}$ & $410 \mathrm{~mm} \times 410 \mathrm{~mm}$ \\
\hline $\begin{array}{l}\text { Thickness of the } \\
\text { boards }\end{array}$ & $19 \mathrm{~mm}$ (sanded) & $19 \mathrm{~mm}$ (sanded) & $19 \mathrm{~mm}$ (sanded) & $19 \mathrm{~mm}$ (sanded) & $19 \mathrm{~mm}$ (sanded) & 19 mm (sanded) \\
\hline Binder type & $\begin{array}{l}\text { UF-resin, BASF K } \\
350 \text { ( } 65 \% \text { solids } \\
\text { content) }\end{array}$ & $\begin{array}{l}\text { TF-resin ( } 45 \% \\
\text { solids content) }\end{array}$ & $\begin{array}{l}\text { UF-resin, BASF K } \\
350 \text { ( } 65 \% \text { solids } \\
\text { content) }\end{array}$ & $\begin{array}{l}\text { TF-resin ( } 45 \% \\
\text { solids content) }\end{array}$ & $\begin{array}{c}\text { UF-resin, BASF K } \\
350 \text { ( } 65 \% \text { solids } \\
\text { content })\end{array}$ & $\begin{array}{l}\text { TF-resin ( } 45 \% \\
\text { solids content) }\end{array}$ \\
\hline Type of tannin & & $\begin{array}{c}\text { Colatan GT } 5 \\
\text { Industria Argentina }\end{array}$ & & $\begin{array}{c}\text { Colatan GT } 5 \\
\text { Industria Argentina }\end{array}$ & & $\begin{array}{c}\text { Colatan GT } 5 \\
\text { Industria Argentina }\end{array}$ \\
\hline Binder level & $\begin{array}{c}\text { Surface layer } 10 \% \\
\text { (solids based on o.d. } \\
\text { particles) } \\
\text { Core layer } 8 \% \\
\text { (solids based on o.d. } \\
\text { particles) }\end{array}$ & $\begin{array}{c}\text { Surface layer 14\% } \\
\text { (solids based on o.d. } \\
\text { particles) } \\
\text { Core layer } 12 \% \\
\text { (solids based on o.d. } \\
\text { particles) }\end{array}$ & $\begin{array}{c}\text { Surface layer } 10 \% \\
\text { (solids based on o.d. } \\
\text { particles) } \\
\text { Core layer } 8 \% \\
\text { (solids based on o.d. } \\
\text { particles) }\end{array}$ & $\begin{array}{c}\text { Surface layer 14\% } \\
\text { (solids based on o.d. } \\
\text { particles) } \\
\text { Core layer 12\% } \\
\text { (solids based on o.d. } \\
\text { particles) }\end{array}$ & $\begin{array}{c}\text { Surface layer } 10 \% \\
\text { (solids based on o.d. } \\
\text { particles) } \\
\text { Core layer } 8 \% \\
\text { (solids based on o.d. } \\
\text { particles) }\end{array}$ & $\begin{array}{c}\text { Surface layer } 8 \% \\
\text { (solids based on o.d. } \\
\text { particles) } \\
\text { Core layer } 10 \% \\
\text { (solids based on o.d. } \\
\text { particles) }\end{array}$ \\
\hline Hardener & Ammoniumsulfate & & Ammoniumsulfate & & Ammoniumsulfate & \\
\hline $\begin{array}{c}\text { Added } \\
\text { formaldehyde }\end{array}$ & & $\begin{array}{c}10.5 \% \text { (active } \\
\text { formaldehyde based } \\
\text { on o.d. tannin) }\end{array}$ & & $\begin{array}{c}10.5 \% \text { (active } \\
\text { formaldehyde based } \\
\text { on o.d. tannin) }\end{array}$ & & $\begin{array}{c}\text { Surface layer } 6.5 \% \\
\text { (active } \\
\text { formaldehyde based } \\
\text { on o.d. tannin) } \\
\text { Core layer } 8.5 \% \\
\text { (active } \\
\text { formaldehyde based } \\
\text { on o.d. tannin) }\end{array}$ \\
\hline Hardener level & $\begin{array}{c}\text { Surface layer } 3.0 \% \\
\text { Ammoniumsulfate } \\
\text { (solids based on o.d. } \\
\text { resin) } \\
\text { Core layer } 3.0 \% \\
\text { Ammoniumsulfate } \\
\text { (solids based on o.d. } \\
\text { resin) }\end{array}$ & & $\begin{array}{c}\text { Surface layer } 3.0 \% \\
\text { Ammoniumsulfate } \\
\text { (solids based on o.d. } \\
\text { resin) } \\
\text { Core layer } 3.0 \% \\
\text { Ammoniumsulfate } \\
\text { (solids based on o.d. } \\
\text { resin) }\end{array}$ & & $\begin{array}{c}\text { Surface layer } 3.0 \% \\
\text { Ammoniumsulfate } \\
\text { (solids based on o.d. } \\
\text { resin) } \\
\text { Core layer } 3.0 \% \\
\text { Ammoniumsulfate } \\
\text { (solids based on o.d. } \\
\text { resin) }\end{array}$ & \\
\hline $\begin{array}{c}\text { Pressing } \\
\text { temperature }\end{array}$ & $190^{\circ} \mathrm{C}$ & $190^{\circ} \mathrm{C}$ & $190^{\circ} \mathrm{C}$ & $190^{\circ} \mathrm{C}$ & $190^{\circ} \mathrm{C}$ & $190^{\circ} \mathrm{C}$ \\
\hline Pressing time & $\begin{array}{c}10 \mathrm{~s} / \mathrm{mm} \text { (exl. } \\
\text { closing time of the } \\
\text { press) }\end{array}$ & $\begin{array}{c}20 \mathrm{~s} / \mathrm{mm} \text { (exl. } \\
\text { closing time of the } \\
\text { press) }\end{array}$ & $\begin{array}{c}10 \mathrm{~s} / \mathrm{mm} \text { (exl. } \\
\text { closing time of the } \\
\text { press) }\end{array}$ & $\begin{array}{l}20 \mathrm{~s} / \mathrm{mm} \text { (exl. } \\
\text { closing time of the } \\
\text { press) }\end{array}$ & $\begin{array}{c}36 \mathrm{~s} / \mathrm{mm} \text { (exl. } \\
\text { closing time of the } \\
\text { press) }\end{array}$ & $\begin{array}{c}45 \mathrm{~s} / \mathrm{mm} \text { (exl. } \\
\text { closing time of the } \\
\text { press) }\end{array}$ \\
\hline
\end{tabular}

The surfaces of the particleboards were coated with a nitrocellulose lacquer primer in an airconditioned paint application chamber under a high volume, low pressure finishing process. When the primer was cured the thickness of its layers was controlled according to the method outlined in DIN method 50986. The adhesion of primer to the surface was measured using UNE-standards 48032 for adherence strength and-EN 438-2, article 6 for abrasion strength. 


\section{RESULTS AND DISCUSSION}

From Table 3, UF- and TF-bonded boards with recycled particles showed the highest average surface roughness values $\left(\mathrm{R}_{\mathrm{a}}\right.$ ) of $11.2 \mu \mathrm{m}, 7.0 \mu \mathrm{m}$ respectively. The $\mathrm{R}_{\mathrm{a}}$-values for uncoated UF- and TFbonded particleboards with fresh particles ranged between $5.2 \mu \mathrm{m}$ and $5.6 \mu \mathrm{m}$. The lowest roughness values were measured for uncoated particleboards with cork particles in the surface layer $(3.1 \mu \mathrm{m}$ and $4.3 \mu \mathrm{m}$ respectively).

For each board the thickness of the coating film was measured. Coated UF- and TF-bonded particleboards, with fresh and cork particles in the surface layer, showed similar thickness of the coating film with values ranging from $115 \mu \mathrm{m}$ to $130 \mu \mathrm{m}$. In comparison the coating film on UF- and TF-bonded particleboards with recycled particles was much thinner. The values ranged from $56 \mu \mathrm{m}$ (UF-bonded particleboards) to $82 \mu \mathrm{m}$ (TF-bonded particleboards), although the amount of primer applied to all six particleboards was constant over the whole experiment $\left(0.15 \mathrm{~g} / \mathrm{cm}^{2}\right)$.

The differences in thickness of the coating film between UF-bonded particleboards and TFbonded particleboards may be due to a many reasons, e.g., the difference in the moisture content of the boards, hygroscopic effect of TF-resins, differences in the curing conditions and homogenous application of the paint.

The results reveal that an acid cured nitrocellulose primer has the same thickness on particleboard made from fresh particles and from cork. The thickness of the finishing on boards with recycled particles was much less than that of the other two cases. This may be due to the high roughness of the surface of recycled boards and consequently to their higher porosity.

Table 3: Coating properties of UF- and TF-bonded particleboards coated with nitrocellulose lacquer primer, made using different raw materials in the surface layers (fresh particles, recycled particles and cork particles).

\begin{tabular}{|c|c|c|c|c|c|}
\hline $\begin{array}{c}\text { Raw material } \\
\text { in the surface } \\
\text { layer }\end{array}$ & Binder & $\begin{array}{c}\text { Average } \\
\text { roughness } \\
\mathbf{R}_{\mathbf{a}} \text { (uncoated) } \\
\mu \mathrm{m}\end{array}$ & $\begin{array}{c}\text { Adherence } \\
\text { strength } \\
\text { Range of values } \\
\mathbf{0}-\mathbf{5}^{*}\end{array}$ & $\begin{array}{c}\text { Thickness of } \\
\text { coating film } \\
\mu \mathrm{m}\end{array}$ & $\begin{array}{c}\text { Abrasion } \\
\text { cycles }\end{array}$ \\
\hline Fresh particles & UF-resin & 5.2 & 4 & 120 & 109 \\
\hline TF-resin & 5.6 & 4 & 115 & 118 \\
\hline $\begin{array}{l}\text { Recycled } \\
\text { particles }\end{array}$ & UF-resin & 11.2 & 4 & 56 & 36 \\
\hline TF-resin & 7.0 & 4 & 82 & 53 \\
\hline Cork particles & TF-resin & 4.3 & 2 & 126 & 36 \\
\hline
\end{tabular}

(*The standard is an optical method. 6 grades of values are possible. The values range between 0 (which means total displace of the paint after the test) and 5 (which means no paint displacement, painted surface is unharmed).

The adhesion plays an important role in the quality of the finishing. Coating systems need a substrate that permits primarily a mechanical link. Table 3 shows in general the influence of roughness on the adherence strength. Particleboards made with fresh and recycled particles showed higher roughness and therefore higher adherence strength compared to particleboards with cork particles, which had a relatively smooth surface. The presence of rough surfaces helps in the anchorage of the applied coating 
systems. A rough surface gives paints several possibilities to penetrate and create "fingers of resin", which helps in developing strong joins. On the other hand very high roughness has negative effects as high cost due mainly to excessive volume of paint necessary to give surfaces smooth appearances.

The abrasion resistance of the finished surface layers of the particleboards was tested according to abrasion strength standard EN 438-2. From the Table 3 large differences were found between the particleboards types. UF- and TF-bonded particleboards made with fresh particles in the surface layer have a much higher abrasion resistance (109 cycles and 118 cycles respectively) compared to particleboards made with recycled particles ( 36 cycles and 53 respectively) and cork particles (36 cycles and 36 respectively).

From the results in Table 3 the relative thickness of the coating film on boards with fresh particles responsible for the higher abrasion resistance. Nevertheless, other different physical and chemical interactions between the different layers of nitrocellulose lacquer primer materials used can also responsible for the difference of abrasion strength.

Comparing particleboards made with fresh and cork particles in the surface, the abrasion strength of particleboards with fresh particles was about three times higher than boards with cork particles, though both type of boards showed similar coating film thickness and also more or less similar average roughness of the uncoated surface. This result can be attributed to different chemical compositions of both raw materials. Cork has a relative high content of suberin, which is responsible for the general hydrophobic nature of cork. As a consequence, the adhesion of primer on cork surfaces is relatively poor and therefore the energy needed to remove the painted cork surface layer is much lower than that needed in the other cases.

It can be concluded that not only the roughness of the surface but also the chemical interaction between the primer and surface is a very important factor for the adhesion of primer on the surface.

\section{CONCLUSION}

The results reveal that, in general, higher values of roughness of uncoated particleboards lead to thinner coating films on the surface.

Particleboards made with fresh and recycled particles showed higher values of average roughness $\left(\mathrm{R}_{\mathrm{a}}\right)$ and higher adherence strength to the coating compared to particleboards with cork particles, which had a relatively smooth surface.

Not only the roughness of the surface but also interaction between the primer and surface seems to be a very important factor determining the strength of adhesion between primer and the surface

\section{BIBLIOGRAFIA}

Barbu, M.; Resch,H.; Pruckner, M.2000. The wettability of medium density fibreboards. Proceedings of the 4th European Panel Products Symposium, Llandudno, Wales, 11th - 13th October 2000: 1421

Cassens, D.L.; and Feist, W.C. 1991. Exterior wood in the South. Selection, application and finishes. GTR-69. USDA Forest Serv., Forest Prod. Lab., Madison, Wis. 56 pp.

Hiziroglu,S.; Graham,M. 1998. Effect of press closing time and target thickness on surface roughness of particleboard. Forest Products Journal 48(3):50-54

Östman, B. 1983. Surface roughness of wood based panels after aging. Forest Products Journal 33 (7): $35-42$ 
PDI. 1998. Surface metrology guide-home. Precision Divices Inc. http://www.predev.com/smg/

Richter, K.; Feist, W.C.; Knaebe, M.T. 1995. The effect of surface roughness on the performance of finish. Part 1. Roughness characterization and stain performance. Forest Products Journal 45 (7-8): 91-96 